Role of Educational and R\&D Institutions in City Clusters: An Exploratory Study of Bangalore and Pune Regions in India

Rakesh Basant

Pankaj Chandra

W.P. No. 2006-02-01

February 2006

The main objective of the working paper series of the IIMA is to help faculty members, Research Staff and Doctoral Students to speedily share their research findings with professional colleagues, and to test out their research findings at the pre-publication stage

INDIAN INSTITUTE OF MANAGEMENT

AHMEDABAD-380 015

INDIA 


\title{
Role of Educational and R\&D Institutions in City Clusters: An Exploratory Study of Bangalore and Pune Regions in India
}

\author{
Rakesh Basant \\ Pankaj Chandra \\ Indian Institute of Management Ahmedabad, India \\ Corresponding e-mail: rakesh@iimahd.ernet.in
}

\begin{abstract}
This paper explores the role played by academic institutions in Bangalore and Pune cities of India. It shows that there exists a large variety of linkages between industry and academia in the two Indian cities; a hierarchy of institutions satisfies a hierarchy of local demands ranging from skills to new technologies. While labor market linkages continue to dominate, global and local changes are creating opportunities for knowledge based linkages. With enhanced competition and privatization of research and education, these linkages are bound to undergo significant change in the future and policy should facilitate this transition.
\end{abstract}

Key words: India, South Asia, spatial clusters, academia-industry linkages

\section{Acknowledgment}

This is a revised version of a paper presented at Research Conference on University-Industry Linkages in Metropolitan Areas in Asia sponsored by the World Bank and the Social Science Research Council and held at Washington DC on November 17-18, 2005. Comments provided by Eric Hershberg, Kaoru Nabeshima, Gayatri Saberwal, Shahid Yusuf and the conference participants were extremely useful. Authors are also thankful to Radhika, Rajesh and Debaroti for research support. The usual disclaimers apply. 


\section{INTRODUCTION}

Studies on University-Industry Linkages (UILs) in the US and European clusters ${ }^{1}$ bring out that a variety of linkages exist between R\&D institutions/universities and firms in the proximity in high tech city clusters, although non-local linkages are often equally large. Besides, the size, innovativeness and strategies of local firms influence the nature and extent of UILs in a geographically bound cluster. As the characteristics of city clusters change, existing linkages may deepen and new ones may get formed. Very little, however, is known about the role played by academic institutions in city clusters of developing countries. Bangalore and Pune have emerged as dynamic city clusters in India. A large number of academic institutions are also located in these cities. This paper explores the role played by academic institutions in these cities. It shows that the variety of UILs in the two Indian cities is large. While labor market linkages continue to dominate, global and local changes are creating opportunities for knowledge based linkages. With enhanced competition and privatization of research and education, these linkages are bound to undergo significant change in the future and policy should facilitate this transition.

The rest of the paper is organized in four sections. Section 2 develops a framework to analyze the role of academic institutions in a city cluster. It delineates the variety of linkages that an institution can potentially have in a cluster and how these linkages may change with different developments in the cluster, in the rest of the economy and in the world as a whole. Section 3 briefly analyses the survey data of electronics and IT firms in three city clusters (Bangalore, Pune and the National Capital Region (NCR)) and in non-cluster regions to understand the perception of firms about the role played by academic institutions and their importance. The data collected from some academic institutions in Pune and Bangalore is analyzed in section 4 to bring out the variety of roles different types of institutions play in these regions. This section also explores the roles played by two well-known academic institutions in the region, namely Indian Institute of Science (IISc), Bangalore and National Chemical Laboratory (NCL), Pune. The final section makes some concluding remarks.

\section{PLACING ACADEMIC INSTITUTIONS IN A CITY CLUSTER: A FRAMEWORK}

Academic institutions interact with a city cluster in a variety of ways (Figure 1). These interactions can be defined at two levels - linkages with other entities in the city cluster and the strength of activities that characterize these linkages. These may include:

1. Labor market related linkages

2. Linkages for demand \& supply of goods \& services

3. Linkages to create New Enterprises

4. Linkages for creation, acquisition \& dissemination of knowledge

5 .

[Figure 1 here]

Availability of certain capabilities in the institution may lead to building of some of these linkages in the city cluster and exploitation of available opportunities. Specific needs of the city cluster can also result in the building of required capabilities at the institution level. In a dynamic sense, therefore, the city cluster and the institutions may co-evolve. Moreover, an Institution can also have similar linkages with entities outside the city cluster. The co-existence of "external" and "internal" linkages may create spillover benefits for the city cluster.

Capabilities of both the institution and the city cluster evolve differentially based on the strengths of these linkages. These linkages are characterized by a hierarchy of activities that vary by the 
extent of capabilities required to deliver them. The location of a linkage in this hierarchy defines the strength of this linkage. For example, an undergraduate engineering school which is not research oriented caters primarily to provide basic talent to the local market. A research-based engineering school may interact with local organizations, in addition to providing basic talent, on $R \& D$ projects. At the same time the ability of local entities to acquire and absorb knowledge from academic institutions may be critical for these linkages to build.

\section{Labor Market Related Linkages}

Academic institutions seek students and professionals for managing their operations, many of whom come from local communities (e.g., visiting faculty from industry). Similarly, students trained at these institutions become part of the regional labor pool. As city clusters become major academic centers, they attract better students and professionals from outside the cluster. In doing so, they expand the labor supply and bring new skills to organizations operating in the city. Availability of such a large labor pool can potentially attract enterprises to the city. There can also be cases where academic institutions do not interact much with the local economy. This can partly be attributed to the state of the local economy in terms of the level of economic development and the structure of local industry.

Academic institutions also respond to emerging skill needs of existing organizations by establishing new programs and courses. New institutions focusing on these needs also emerge over a period of time. Different academic institutions typically cater to different kinds of skill demands. As cities evolve and develop, the mix of skill requirements from academic institutions undergoes a change. Given the complementarities between research and teaching, a research oriented academic institution is likely to provide a higher value of skill input. In other words, there exists a hierarchy of academic institutions that participate in the labor market of the city cluster.

\section{Linkages for Demand \& Supply of Goods \& Services}

Academic institutions create a demand for variety of goods and services which are required to run the institution. These may range from infrastructure to consumables to equipments. At the same time they may provide a variety of services to the city cluster like testing, training, certification, consulting, prototype development etc. Establishment of an institution also leads to demand for infrastructure to support the student population. City clusters that become educational hubs can have a significant impact on the local market for infrastructure like housing, transport, water, sanitation etc. as well as commodities for local consumption.

\section{Linkages to Create New Enterprises}

Spin-offs from academic institutions have received a lot of attention in recent times especially in hi-tech city clusters. Technologies developed in the institutions (especially research oriented) are commercialized through new enterprises wherein students and faculty may participate. Many cities around the world have created facilities like science parks and incubators around research based academic institutions to create economic wealth in the region.

\section{Linkages for Creation, Acquisition \& Dissemination of Knowledge}

Linkages between academic institutions and industry in this domain can take a variety of forms student projects, technology licensing, consulting, industry-institution R\&D projects, seminars \& workshops, guest lectures, specialized training programs, internships, etc. These linkages are very sensitive to the nature of academic institution and local organizations, including the sectoral and structural features of local industry. Typically, R\&D oriented organizations are more likely to 
have such linkages. This is so because the absorptive capacity of the local organizations is critical for any knowledge based linkages. For example, estimates from Japan suggest that for many years large organizations dominated the linkages between industry and academia. This is changing as more and more research oriented SMEs seek more academic interaction to complement their limited in-house R\&D capabilities (Motohashi, K, 2004). There is also some evidence to suggest that certain sectors (especially science based) are more amenable to the building of such linkages (Mowery and Sampat, Undated; Graff et. al., 2002). A corollary of this can be that the sectoral profile of the cities' industrial sector would affect the incidence and intensity of such linkages. Changes in sectoral profile will not only impinge on the formation of knowledge networks but also affect the other three linkages. In other words, characteristics of the city cluster can impinge on the nature of UILs. Moreover, other exogenous changes like shifts in technology and/or the nature of global industrial structures can also affect these linkages. Nature of linkages external to the cluster can affect linkages that are internal to the city. We shall revert to these issues in a subsequent section.

Many of these linkages can be informal in nature. For example, most academic institutions in developing countries do not have formal "technology transfer/consulting" offices. There is also evidence to show that till very recently even in developed countries like Japan, the UILs were informal in large measure to avoid the cumbersome official procedures for handling patentable inventions (Geiger, R L, 2001. Also see Branscomb et al. 1999).

Finally, while Federal and State policies (including those related to trade, investment and education) may affect the formation of all four types of linkages, city specific initiatives as facilitators have received major attention in recent years. Efforts of cities like Bangalore and Pune in India have led to both becoming educational and industrial hubs in the country. For example, land at concessional rates for educational institutions, setting up of science parks, improvement of city infrastructure, attracting foreign and local investments in education and industry, etc. have played a critical role in promoting their cities as important hubs for educational and industrial activity.

To conclude this section a few things need to be re-emphasized. The nature and strength of all the four linkages in a city cluster are a function of the level of economic development of the location and the structure of the urban economy. As the urban economy diversifies and/or matures, one may expect larger role of educational institutions in new enterprise creation, R\&D and technology transfer; else labor market links may dominate. Similarly, the potential of UILs would be influenced by the sectoral profile of local industry. For example, existence of science based manufacturing sector in the vicinity may create more opportunities for local UILs than in situations where institutions are located in the proximity of traditional or artisan sector firms. In the same vein, the nature of linkages would be different in city clusters dominated by the services sector from those where the manufacturing sector is strong.

\section{ACADEMIC INSTITUTIONS AND CITY CLUSTERS: PERCEPTIONS OF FIRMS}

In a recent survey ${ }^{2}$, firms in the Bangalore, Pune, the NCR clusters and some non-cluster areas were asked about the advantages they get by locating in the city where they operate. The data show that firms in both cluster and non-cluster areas perceive basic educational facilities, centers for technical education, consultancy services and technology development centers to be quite important. ${ }^{3}$ Do firms see academic institutions as a significant advantage in a city cluster? Firms in both Bangalore and Pune clusters, rate access to skilled labor as the most important advantage (with a rating of 3.99 and 3.98 respectively on a five point scale) of locating in these cities (Table 1). This strongly recognizes the role of academic institutions as key suppliers of labor in the market especially in the knowledge sectors of IT and Electronics. Besides, cluster firms found the 
advantage of having access to specialized services like training, R\&D services and facilities etc. to be quite high. Interestingly, here on average the Bangalore firms found this advantage to be slightly better than the Pune firms. Another interesting result is that firms in Bangalore and Pune seem to be better placed in terms of access to skilled labor and R\&D institutions than the NCR region. As expected, firms located in cities where IT and electronics cluster do not exist (noncluster firms) are not as well placed in terms of all the three areas (access to skills, training and $\mathrm{R} \& \mathrm{D}$ facilities) as the cluster firms; their average score is significantly lower than those of the cluster firms.

[Table 1 here]

Overall, the survey results suggest that as compared to other regions, Pune and Bangalore cities are better equipped to provide services that are typically provided by academic institutions. While the role of institutions as a key source of labor is widely recognized, other linkages are formed as firms in a city cluster go up on the capability ladder or start to service complex order requirements of advanced customers. Therefore, higher perceived advantages of academic institutions among Bangalore and Pune firms could also be reflective of how the city clusters have evolved to date and may be indicative of the demand (and likely supply) for the nature of institutions and the accompanying capabilities.

\section{Table 2 CITY CLUSTER AND ACADEMIC INSTITUTIONS: CASES OF PUNE AND BANGALORE}

As mentioned, changes in the composition of the city cluster can have a significant impact on the UILs. While no systematic documentation of the processes could be done, a few inter-related developments seem to be affecting the nature of the Bangalore and Pune clusters, which in turn are creating new impulses for UILs. These are: continuing globalization of IT markets, changes in the composition of the Indian IT sector, emerging globalization of drug development processes and significant changes in drug discovery and IT technologies.

\section{Globalization and Deepening of Labor Markets}

Changes in the structural characteristics of the market in a city can have a significant impact on the characteristics of local labor market. For example, "globalization" of IT markets can potentially lead to significant deepening of labor markets. Market deepening usually refers to the process where the market increasingly extends itself to new areas of human activity. Extending this idea, one can argue that as transactions in a specific market become more frequent, complex and diverse, one would say that market deepening is taking place. In a sense market deepening can be seen as a result of two simultaneously occurring phenomena. As market grows specialization takes place and diversity in the demand and supply of skills gets enhanced. We refer to this as the deepening process. But as demand for specialized skills grows, the market segment for each set of skills becomes large. The increase in scale for each skill segment makes its market "thick" as more and more entities demand and supply these skills frequently. Thus, thickening and deepening of markets can be seen as two interdependent dimensions of the market expansion process and in some sense market deepening encompasses the thickening of the market as well. ${ }^{4}$ Academic institutions and city clusters need to be placed in the evolving process of labor market deepening as they can facilitate such deepening by satisfying emerging skill requirements and also supplying skills that would generate demand for specific skills in the future. Such market deepening processes can be quite important for the role played by academic institutions especially in IT and other science based sectors. ${ }^{5}$

So far, the development of the IT labor market in India has been essentially driven by the integration of IT related activities globally. Over reliance on the export markets for growth in the 
last decade has meant that growth in demand for low-end skills has dominated. ${ }^{6}$ There has been a rapid increase in the offshore segment of the Indian software and services exports. ${ }^{7}$ The transition from the onshore to the offshore model deepened the IT labor market in India as Indian firms could now utilize the segmentation in the labor market to their advantage; workers with different skills can now be used for different tasks all of which were earlier done by high skilled workers onsite. The IT sector in India is also getting diversified in terms of domains (telecom, banking etc.) and slowly moving up the value chain. ${ }^{8}$ Changes in composition of the IT sector combined with the offshore model can potentially create larger opportunities of employment for workers with different characteristics. Consequently, more people with different skill-sets and educational backgrounds can now participate in the IT labour markets.

\section{Changes in IT and Drug Development Technologies and Emerging Collaboration Opportunities}

Similarly, changes in IT and drug discovery technologies are changing global production and $R \& D$ structures creating opportunities for firms in India to participate in these emerging networks. This in turn can have an impact on UILs. For example, new technologies (especially the SOC based ones) $)^{9}$ and convergence of different disciplines in drug discovery are creating opportunities in specialized high-tech areas ${ }^{10}$ that many Indian firms have started to exploit, often with the help of academic institutions. ${ }^{11}$ Since intellectual property would be important in such initiatives, an appropriate IPR regime and well defined rules regarding sharing of IP in academic institutions may increasingly become important. An appropriate IPR regime $e^{12}$ combined with the above mentioned technological developments may also lead to creation of networks and alliances between firms having diverse capabilities on the one hand and educational institutions \& public sector entities on the other.

Broadly then, technological change and globalization processes affect UILs as the skill profile of IT workers demanded undergoes a change with such developments. The important thing to note is that such transitions enlarge the skill requirements in the labor market and skill needs both at the low and high ends of the spectrum are expected to rise.

\section{Emergence of Biotech and Diversification of Bangalore and Pune Clusters}

Bangalore is the top ranking IT cluster in the country but Pune has picked up in recent years. Some believe that it will soon become number two in the IT sector (De, 2004). Both cities have a plethora of good engineering and other professional colleges. These educational institutions attract students from all over the country creating a vibrant student community and a talented labor pool (De, 2004). ${ }^{13}$ In recent years, these cities have emerged as premier bio-tech clusters in the country. The growth of bio-tech segment of the Bangalore cluster, which has about 80 firms, has been facilitated by the presence of many prestigious research-cum-teaching institutions in the city. While IISc has existed for several years, most of others have been set up in recent years, partly in response to emerging technological opportunities and industry needs. These include, National Center for Biological Science set up in 1991 to pursue R\&D in biochemistry, biophysics, bio-informatics, neurobiology, cellular organization \& signaling and genetics. In addition, Jawaharlal Nehru Centre for Advanced Scientific Research established in 1980, has increasingly focused on (apart from other things) human genetics. The state government of Karnataka had set up a Vision Group on Bio-technology as a public-private partnership to evolve a Biotechnology Policy for the State. On the recommendation of the Vision Group, Institute of Bioinformatics and Applied Biotechnology (IBAB) was set up to train bio-informaticians for the industry. In addition, a Bio-tech park is being set up to house an incubator facility, a common facility for shared instrumentation and a patent cell.

While IISc contributed significantly to the growth of the bio-cluster in Bangalore, NCL has provided a major advantage to the Pune cluster. In addition, the Pune University, with one of the 
best bio-informatics programmes in the country, has also played an important role. A bio-tech park is being set up in Pune as well and will house a pilot plant facility for start up firms to lease.

Both Pune and Bangalore clusters have diversified over the years. Pune region is emerging as a center that has firms in IT, bio-technology, pharmaceuticals, and auto-components. Bangalore covers IT and biotechnology, but also includes several other segments like telecom, machine tools, etc. There is evidence to show that diversity is on the rise even within sectors in both Pune ${ }^{14}$ and Bangalore. ${ }^{15}$ The presence of the large pharma sector in Pune is expected to further facilitate emergence of new firms in the areas of bio-therapeutics, diagnostics, and veterinary products. On both locations the interface between IT and bio-technology would further enhance the diversity. The educational institutions would play a significant role in the process.

\section{Academia-Industry Linkages and the Hierarchy of Institutions in Bangalore and Pune}

Given the discussion so far, it is obvious that different types of academic institutions have different roles to play in a city. The nature of linkages that they can potentially have is dependent on their own profile and the features of the city. It is difficult to fully characterize the hierarchy of academic institutions but we looked closely at 14 (7 each in Bangalore and Pune) to explore the dimensions that can define the elements of this hierarchy. Research versus teaching orientation can be an important dimension of this hierarchy. Institutions with very heavy teaching loads might not be able to devote resources for knowledge based linkages. It can be expected that institutions with similar profile (or at same level of hierarchy) are more likely to interact with each other. In order to facilitate the discussion of the linkages these institutions have in the city clusters, we follow the four-fold classification of linkages described in section 2.

Labor Market Linkages: The role of an academic institution in the local labor market is a function of its size and the kind of education it imparts. The skills imparted may be in any discipline like engineering, medicine, pharmacy etc. The level of education may be at the undergraduate, postgraduate or doctoral level; it can also offer diploma courses. Moreover, an institution may be specialized (e.g., bio-informatics, specific courses in IT) or general, offering a variety of courses (e.g., an engineering school offering courses in different branches of engineering). In addition to its regular courses, the institutions can also provide short-term training programs that are often specific to local industry needs. There can also be institutions which do not offer any teaching programs and only undertake research.

[Table 2 here]

Table 2 shows that among our sample institutions one does not offer any teaching program, while others offer a variety of courses, some only at a very high level (doctoral, as in Agharkar Institute, Pune) while others offer a range of courses (e.g., IIIT, Bangalore offering IT courses at all levels). Although it is difficult to categorize the levels of skills provided, one can say that institutions that offer doctoral programs are offering higher end skills than those which offer other programs. Similarly, an institution offering post-graduate courses can be put higher up in the hierarchy than those which are offering only under-graduate programs. However, some specialized diploma and other courses may also be of a very high level. Interestingly, irrespective of the nature of education imparted, most of the institutions cater to the local labor market as bulk of their students work with city based domestic and multinational firms. However, a fair share of the students in many institutions also works outside the city (Table 3). Thus, the participation of all these institutions in the local market is quite significant. The fact that a large proportion of students with relatively high skills (with post-graduate and doctoral education) are absorbed in the cities suggests that the absorptive capacity of the regions for such skills is high.

[Table 3 here] 
Demand for Goods and Services: The data on these linkages ${ }^{16}$ shows that all institutions interact intensively for their equipment and other purchases with the city entities. Many of them buy things from outside the city while a few buy things from outside the country. Typically, institutions that are at the higher end of research activity also tend to procure their equipment and services globally.

Spin-off Activity: Only two of the sample institutions (IIIT, Bangalore and Agharkar Institute Pune) reported that a firm each has been spun out of the campus. But most institutions interviewed were aware of the possibility and looking for opportunities. In India, spin-offs from academic institutions are still a nascent phenomenon. The respondents were asked about the reasons why faculty and students from their institutions are not able to set up enterprises. Three reasons stand out: lack of seed funding, in-appropriateness of research for commercialization and absence of institutional regulations to set-up firms. These responses are consistent with some available evidence that venture capital industry in India is still in its infancy and start-up funding is not easily available (Morris and Basant, 2005). Research oriented institutions are trying to cope with the IP and other issues (e.g., owning equity in spin-offs) that are very important to set up new enterprises. It is important to note that almost all public funded institutions in India, have traditionally not been allowed to hold equity in ventures. This is being changed through the creation of separate entities within these organizations along with the creation of incubators.

Other Knowledge Based Linkages: As mentioned, the ability of institutions to build knowledge based linkages is a function of the knowledge creating activities undertaken by them. Only 3 of the 14 institutions reported any research or commercialization output in the last five years. ${ }^{17}$ Thus, not all institutions seem to have an adequate knowledge base to participate in knowledge based networking activity. Moreover, only a few of these institutions have systems in place to undertake formal knowledge transfer. None of the institutions surveyed had a separate technology transfer office. As of now, the three institutions having significant research output (IIIT, Bangalore, Agharkar and Tata Center in Pune) have informally identified individuals in the organizations who help in patent filing and licensing activities. They also have arrangements with law firms to help these individuals. Interestingly, apart from these three institutions, three more in the sample have put in place some rules for commercialization of technologies developed in the organization. They seem to be anticipating the need of such norms as more interaction with industry takes place. The rules are similar across institutions: Inventor gets a reward, licensing rights are held either by the institution, sponsor or both and the first right of commercialization is with the sponsor. Only one institution explicitly mentioned that they plan to hold equity in the venture. Another mentioned that they would prefer non-exclusive licenses. Most respondents felt that this activity is likely to rise in the near future and some of them are seeking outside help to facilitate this transition.

Another way of capturing research linkages in a city is to find out if researchers of one educational institution are collaborating with researchers in other local institutions. It is difficult to get detailed information on such linkages. As a proxy, we analyzed the research papers published by the researchers located in Bangalore and Pune and in the two main research institutions of each city - namely IISc and NC (Table 4). Both IISc and NCL had a very large share of all the publications having authors from local academic institutions (universities, colleges etc.) and public research institutes. A few interesting insights stand out. Researchers in these institutions publish very few papers with researchers from local industry. In fact, even if one looks at all types of linkages, international and national co-authorship linkages are much stronger than the city-cluster specific linkages. One of the major reasons for the lack of local research linkages can be the absence of institutions of same stature as IISC and NCL in both Bangalore and Pune. With high teaching loads (e.g., UGC specifies a teaching load of 18 hours per week), local teaching institutions are unable to devote time required for research. 
[Table 4 here]

Despite limited research output and limited preparedness in terms of systems, the sample institutions in both Pune and Bangalore seem to have a variety of linkages with industry (Table 5). Most of these linkages are localized to the city. The linkages captured in the survey seem to differ in following ways:

- Not all institutions are able to raise funding for the activities that they do with industry but some raise resources for virtually all such activities.

- For some, the linkages in the city cluster dominate, while for others both city and non-city based linkages are important. Very few have international linkages.

- While some institutions have high-end linkages for basic and applied research, others primarily undertake training, testing and proto-type development activities along with student projects.

[Table 5 here]

Absence of institutional and policy incentives for researchers/institutions to build linkages, lack of research orientation among local firms and inappropriateness of research undertaken for the industry in the region were cited as the three most important reasons for lack of local linkages.

Overall, the results of the survey of 14 academic institutions suggest that these institutions interact with the city cluster in a rich variety of ways. Some are gearing themselves up to participate in such linkages in a more systematic manner. The hierarchy among the institutions seems to be important for the kind of roles that they can play. It is obvious that few are likely to have the kind of knowledge base to undertake high-end knowledge networking activities with various entities in the city cluster. Just like there is segmentation in the needs of local industry, there are segments among academic institutions to satisfy a variety of demands. Depending on the profile of the institution, it can be restricted to participate only through the labor market or can move the value chain to create technology based new ventures or satisfy a variety of R\&D needs to the firms around the city.

\section{Role of Research Oriented Institutions: The Case of IISc, Bangalore and NCL, Pune}

As suggested earlier, the quality of research and teaching done at an academic institution would affect the nature of linkages it has with entities in a city cluster and elsewhere. IISc, Bangalore and NCL, Pune can be considered as representative of very high-end research oriented academic institutions. There are, of course, several differences between the two institutions some of which need to be mentioned here. While IISc was a creation of a private endeavor (Tata) which subsequently got state support, NCL is part of the Council for Scientific and Industrial Research (CSIR) system of publicly funded research labs set up by the Federal government. The research profile of IISc is much more diverse than that of NCL which essentially focuses on chemical and bio-technologies. In a sense IISc is more like a research university with a wide variety of disciplines while NCL is a top ranking center for research in a specialized field with a vibrant $\mathrm{PhD}$ program. We will come back to some these and other differences later. In what follows we discuss each of these institutions and their linkages with industry in some detail.

IISc Bangalore was established in the year $1909 .{ }^{18}$ Besides, formal education and research, the Institute offers to the industry the know-how generated within the institute through in-house research and industry sponsored projects. More importantly, the institute has been known globally for its excellent quality education and high research output in basic science and allied fields. Although, research focused, IISc was one of the first institutes in the country to have an extension wing for industry interactions. Center for Scientific and Industrial Consultancy (CSIC) was 
established in 1975 to promote the interaction and collaboration between the institute and the industry. Society for Innovation Development was established in 1991 to extend this activity and help enterprises to compete in the global market. IISc have been far ahead of NCL, Pune and other labs in terms of publication activity, but lags behind in patenting activity (Business World, 2003). ${ }^{19}$

Table 6 summarizes the linkages that IISc has built in recent years. Admittedly, we do not have information on all the linkages of the institution as we only had access to public sources. A few patterns are striking:

- IISc has a large variety of linkages in terms of technology and sectoral profile with entities within and outside Bangalore. The local linkages are quite prominent while they also have linkages outside the country.

- The institution has so far spun-out seven companies mainly in the areas of IT and a few in bio-technology.

- A large number of alliances and almost all the new ventures created by them are in areas that have been earlier identified as areas where the potential for collaboration is high namely drug discovery, biotechnology, semi-conductors, other specific IT related areas and combinations thereof (e.g., bio-informatics).

[Table 6 here]

$\mathrm{NCL}^{20}$ was established in 1950 in Pune to carry out research and development in the areas of chemical and related sciences. It is widely considered to be the most distinguished public sector labs and currently has 364 research fellows and around 397 project staff (of which over 300 are $\mathrm{PhDs}$ ). NCL has many inter-disciplinary research centers with interests in polymer science, organic chemistry, catalysis, materials chemistry, chemical engineering, biochemical sciences and process development. The Institute publishes a large number of papers in chemical sciences (approximately 350 per year) and files the largest number of patents from India. On average, NCL is granted about 50 Indian and 25 foreign patents per year. In fact, much of the recent improvement in the public sector labs' patenting record is attributable to NCL (Mani, 2002, Business World, 2003). The institute also produces the largest number of $\mathrm{PhDs}$ in chemical sciences in India.

NCL also has considerable interaction with the industry through consultancy and research projects. During 2002-04, the two year period, NCL earned Rs 1,840 lakhs through industrial projects. About 50 per cent of these earnings were from foreign companies. Contract Research, Consultancy and Technical Services form a large part of NCL's business interactions with external industries. The contract research services principally help in generation of Intellectual property, whereas others provide either professional advice to industry or help firms in terms of testing or other facilities available at the Labs. Besides, NCL has also conducted various training programs for industry personnel on a range of topics. NCL's clients include Indian, foreign and multi-national companies. Besides, NCL has also entered into many academic collaborations with research institutes within India and abroad.

[Table 7 here]

Table 7 summarizes the nature of linkages that NCL has with entities in and outside Pune. Once again, the list is not exhaustive as it is based on publicly available information. The following aspects of these linkages seem to be significant:

- As in the case of IISc, NCL has a diverse set of linkages with entities in the city and outside, including foreign entities. 
- As in IISc, a large number of alliances seem to be in areas of pharmaceuticals and biotechnology that were identified as potential areas of collaboration. There are also linkages to work on the boundaries of IT and biotechnology and chemistry, another area identified earlier.

- But unlike IISc, NCL seems to be working more closely with other academic institutions, particularly with those located in the city. This can partly be a reflection of the fact that unlike IISc, NCL does not have the diversity of disciplines under the same roof to undertake research in the areas that combine bio-technology, IT and chemistry etc. And consequently, they need alliances to get access to complementary capabilities for inter-disciplinary research.

- Another striking difference between IISc and NCL is the absence of spin-offs in the latter. This is quite surprising because NCL is far ahead of IISc in terms of patenting activity, a proxy (admittedly inadequate) of IP creation. This may partly be due to the "public sector" legacy that NCL may have.

To the extent that joint publication activity is indicative of collaborative work, Table 4 provides some interesting insights on these two institutions. Interestingly, while international linkages are very strong, researchers at both NCL and IISc, the premier institutions of the two cities, seem to collaborate fairly strongly with other local academic and public research institutions in the city; about 24 per cent of publications of these institutions had co-authors from other local institutions. Overall, various entities (including firms and other research institutions) in the Pune and Bangalore clusters (and outside) have been able to exploit the research capabilities of NCL and IISc to tap the emerging entrepreneurial and research opportunities identified earlier. The coexistence of academic institutions and firms with requisite capabilities to tap such opportunities has resulted in such interaction to add value to the economic activities of the city clusters.

\section{SOME CONCLUDING OBSERVATIONS}

It is apparent that development in sciences \& technology and changes in global production and R\&D networks have created new opportunities for interaction between academic institutions and firms in India. The evidence from our limited survey suggests that academic institutions and other entities in Pune and Bangalore have utilized these opportunities to build linkages. However, only research institutions like IISc and NCL that have capabilities to exploit these opportunities fully. It is not surprising, therefore, that the two most vibrant economic centers in the country today happen to be Bangalore and Pune.

Our survey reveals a hierarchy of institutions in terms of the strengths of their linkages. Three kinds of institutions emerge: those that undertake only teaching (i.e., linkage through low-end labor market), those that do research and teaching (i.e., having linkages through all four varieties mentioned earlier) and those that focus on specialized research (i.e., linkages that are predominantly driven by knowledge generation and dissemination). For example, Sri Jayachamarajendra Educational Society and Pimpri Chinchwad College of Engineering would belong to the first category; IISC and IIIT would fall in the second; while NCL and Agharkar Research Institute would be part of the third category. There exists, however, a hierarchy of institutions in each of these categories. Perhaps, it is the existence of this hierarchy (that may reflect institutional capabilities) that academic institutions in these city clusters rarely come together to advance these linkages collectively. NCL seems to have done somewhat better than others on this count with several collaborations with other academic institutions in Pune.

Overall, academic institutions of Pune and Bangalore interact with the city clusters in a rich variety of ways. Many are gearing themselves up to participate in such linkages in a more systematic manner. Our analysis suggests that as compared to other regions, Pune and Bangalore cities are better equipped to provide services that are typically provided by academic institutions. But even in these cities, the hierarchy among the institutions seems to be important for the kind of 
roles that they can play and the linkages that they can form. It is obvious that only few have the kind of knowledge base to undertake high-end knowledge networking activities with various entities in the city cluster. But segmentation within academic institutions is relevant to satisfy the variety of demands that emerge over time. However, some deepening of capabilities in different segments seems to be desirable. If knowledge based activities do pick up in a big way, institutions like IISc and NCL will not be able to cater to all requirements.

The Bangalore and Pune experience also broadly supports the idea that institution and industry co-evolve to take advantage of emerging opportunities that arise due to their co-location. Their proximity also creates a potential for exploiting opportunities that arise out of developments outside the city cluster. Such benefits become more pronounced when institutions start to compete with each other to strengthen their linkages with others in the city cluster. So far, academic institutions in India have not competed with each other in any significant manner. It must be mentioned that, till very recently, firms have also not been pro-active in seeking out these linkages to advance their research capabilities. Enhanced competition in recent years seems to have led to a large number of alliances. As this competition intensifies one may see stronger linkages between academic and industry. Therefore, as the city economy matures, one can expect more deepening of these linkages.

Finally, at a broader level, the academia-industry linkages in India need to be analyzed in the context of a few larger processes. Till recently, the private sector in India was not very research oriented partly because of lack of competitive pressures and the bulk of the research was done in public institutions. Within public institutions, barring few exceptions, research has moved out of Indian universities and other academic institutions over the years. For many years, the public sector research institutions have been the main centers of research activity and universities have largely become teaching institutions. This pattern is changing in two ways. One, the private sector has started to engage in research and the academic institutions have started to face financial difficulties which are partly being alleviated through 'sponsored' research. Lack of industry orientation among academic institutions and limited R\&D orientation constrained industryacademia linkages over the years. As both change, one would expect more academia-industry linkages. Research in industry and university is complementary and the success of academiaindustry linkages lies in the exploitation of these complementarities. Instruments that facilitate such exploitation should be the focus of policy action. The much larger challenge, however, is to design appropriate work environments \& compensation packages that will attract talented young people to take up careers in academia. This will go a long way in alleviating the constraints on availability of "research-inclined" faculty in academic institutions, a prerequisite for formation of research based linkages. 


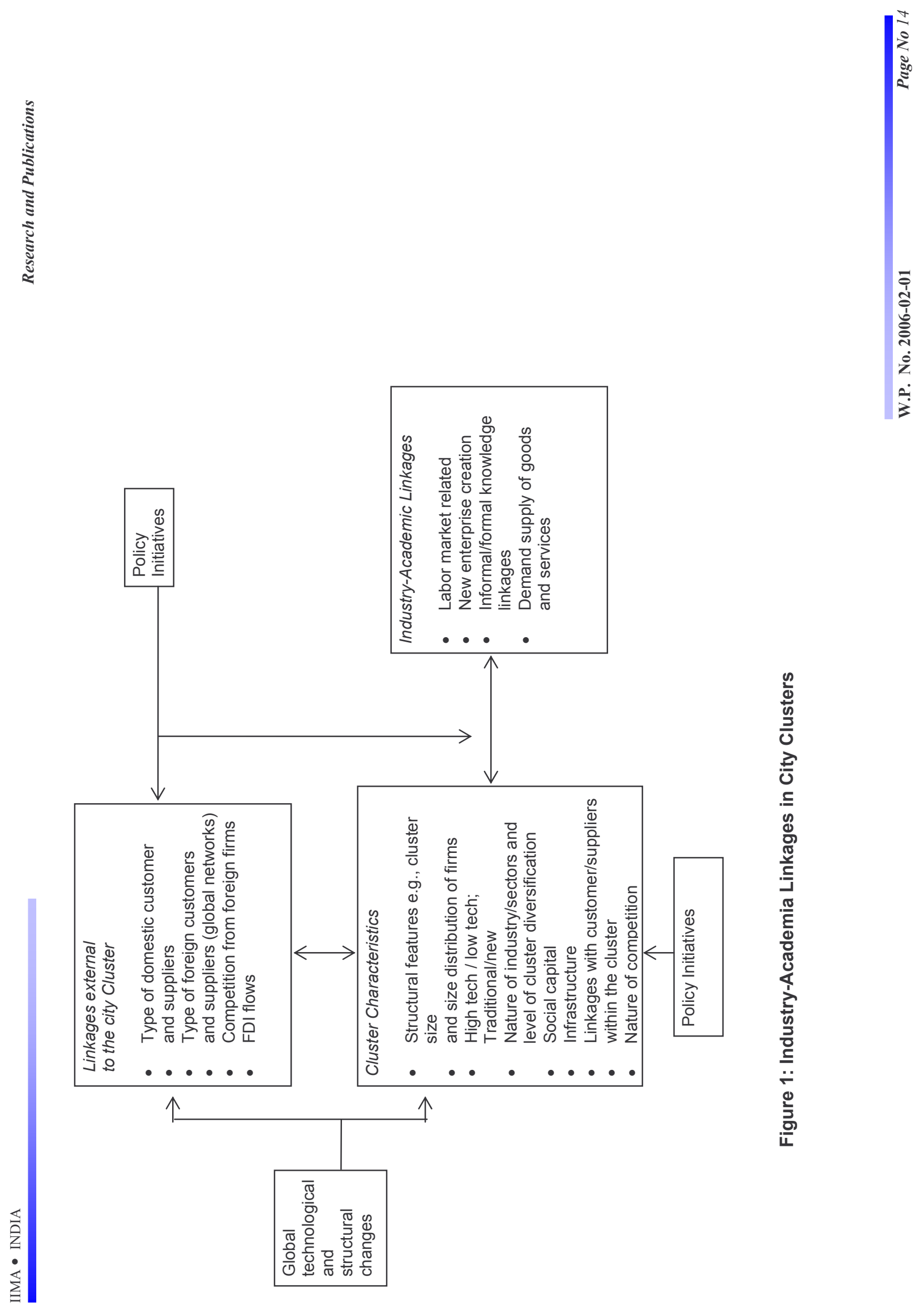




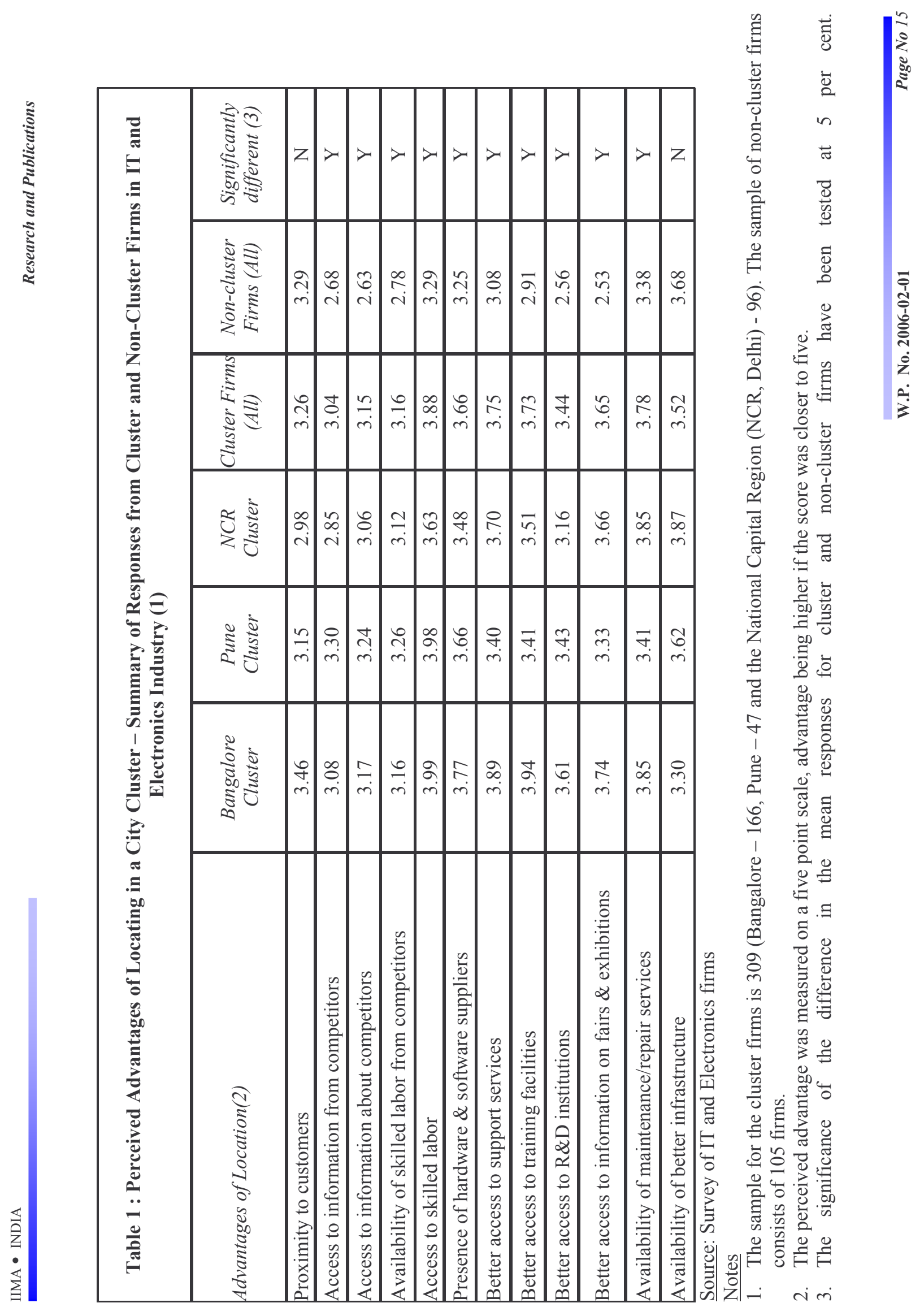




\begin{tabular}{|c|c|}
\hline \multicolumn{2}{|c|}{ Table 2 : Participation in the Labor Market - Teaching Profile of Sample Institutions } \\
\hline Name of the Institution & Course offered \\
\hline \multicolumn{2}{|l|}{ Bangalore Cluster } \\
\hline $\begin{array}{l}\text { Sri Jayachamarajendra Educational } \\
\text { Society }\end{array}$ & $\begin{array}{l}\text { - Undergraduate teaching in engineering- electronics, } \\
\text { mechanical and IT } \\
\text { - Training progras for firms in the city }\end{array}$ \\
\hline $\begin{array}{l}\text { Sri Belimatha Maha Samsthana Institute } \\
\text { of Technology }\end{array}$ & $\begin{array}{l}\text { Undergraduate and post-graduate teaching in } \\
\text { engineering- electronics and IT } \\
\text { - Training programs for firms in the city }\end{array}$ \\
\hline $\begin{array}{l}\text { Indian Institute of Information } \\
\text { Technology }\end{array}$ & $\begin{array}{l}\text { - Undergraduate, post-graduate and doctoral teaching in } \\
\text { IT } \\
\text { Training programs for domestic firms with in and } \\
\text { outside the city and for MNCs in the city, in other parts } \\
\text { of the country and outside }\end{array}$ \\
\hline $\begin{array}{l}\text { Institute of Bioinformatics and Applied } \\
\text { Biotechnology }\end{array}$ & $\begin{array}{l}\text { Post-graduate (diploma) teaching relating to } \\
\text { biotechnology, pharmacology, biology and IT } \\
\text { Training programs for domestic and multinational firms } \\
\text { in and around the city }\end{array}$ \\
\hline $\begin{array}{l}\text { Dr. H.L Thimmegowde College of } \\
\text { Pharmacy }\end{array}$ & $\begin{array}{l}\text { - Undergraduate and post-graduate teaching in } \\
\text { biotechnology, chemistry and pharmacology } \\
\text { - Training programs for domestic and multinational firms } \\
\text { in the city and in other parts of the country } \\
\text { - Training programs for government agencies in and } \\
\text { outside the city }\end{array}$ \\
\hline P.E.S College of Pharmacy & $\begin{array}{l}\text { Undergraduate, post-graduate and doctoral teaching in } \\
\text { chemistry, pharmacology and pharmacy } \\
\text { - Training programs for domestic firms in and around the } \\
\text { city }\end{array}$ \\
\hline East Point College of Engineering & $\begin{array}{l}\text { - Undergraduate, post-graduate and doctoral teaching in } \\
\text { mathematics, electronics, mechanical and IT } \\
\text { Training programs for domestic firms in and around the } \\
\text { city }\end{array}$ \\
\hline \multicolumn{2}{|l|}{ Pune Cluster } \\
\hline Indian Drugs Research & $\begin{array}{l}\text { - Undergraduate, post-graduate and doctoral teaching in } \\
\text { biology, pharmacology and pharmacy }\end{array}$ \\
\hline $\begin{array}{l}\text { Modern Education Society's college of } \\
\text { Engineering }\end{array}$ & $\begin{array}{l}\text { Undergraduate teaching in engineering - electronics, } \\
\text { mechanical and IT } \\
\text { Training programs for domestic and multinational firms } \\
\text { in the city } \\
\text { - Training programs for government agencies in the region }\end{array}$ \\
\hline Indian Institute of Tropical Meteorology & - $\quad$ Undergraduate, post-graduate and doctoral teaching \\
\hline $\begin{array}{l}\text { Tata Research Development and Design } \\
\text { Center }\end{array}$ & - No teaching or training undertaken \\
\hline Agharkar Research Institute & - $\quad$ Doctoral teaching in biotechnology \\
\hline Maharashtra Institute of Pharmacy & $\begin{array}{l}\text { Undergraduate and post-graduate teaching in biology, } \\
\text { chemistry and pharmacology and pharma technology } \\
\text { Training programs for domestic and multinational firms } \\
\text { in and outside the city }\end{array}$ \\
\hline $\begin{array}{l}\text { Pimpri Chinchwad College of } \\
\text { Engineering }\end{array}$ & $\begin{array}{l}\text { - Undergraduate teaching in engineering- electronics, } \\
\text { mechanical, computers and IT }\end{array}$ \\
\hline
\end{tabular}

Source: Survey of academic institutions in Bangalore and Pune. 


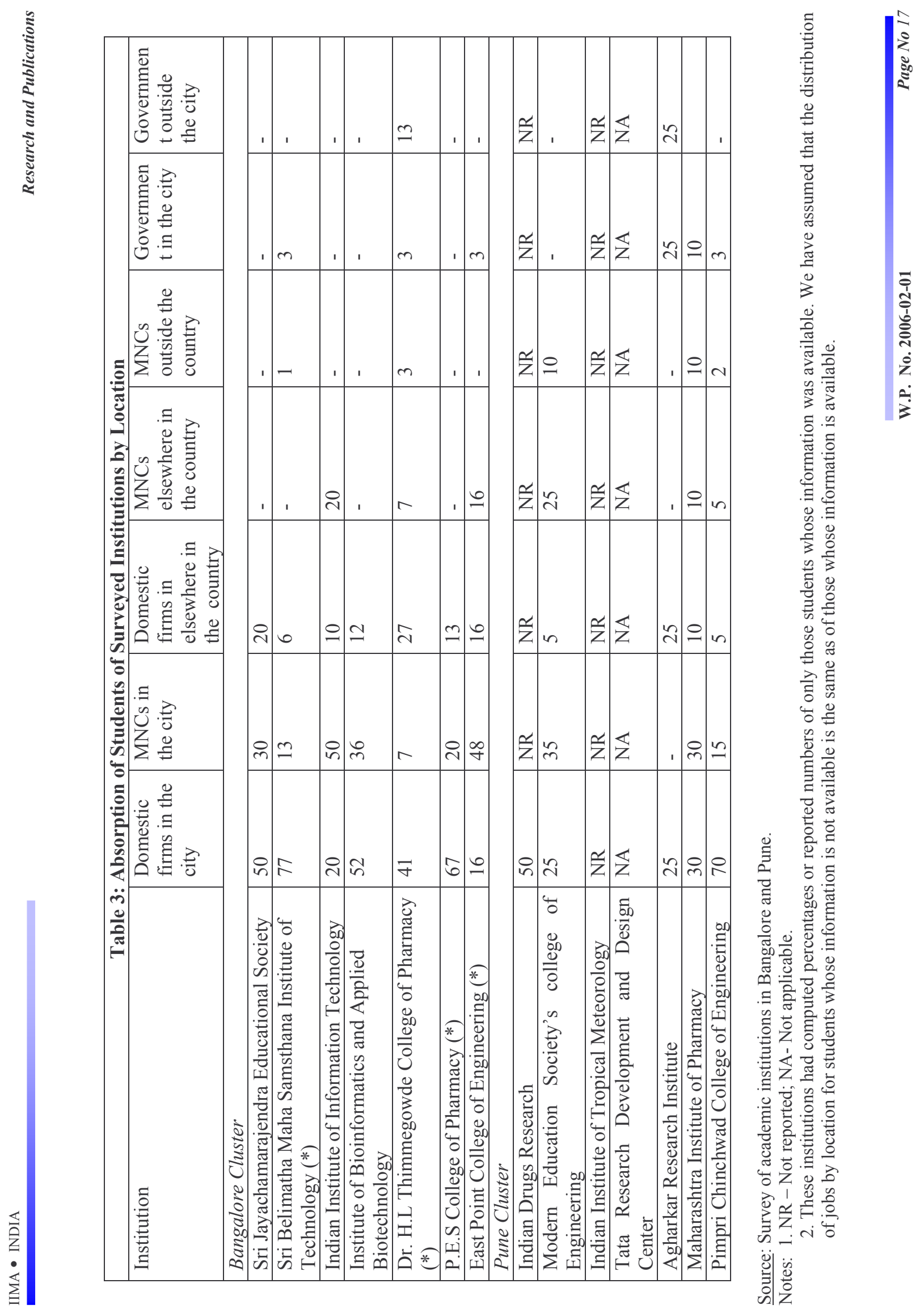




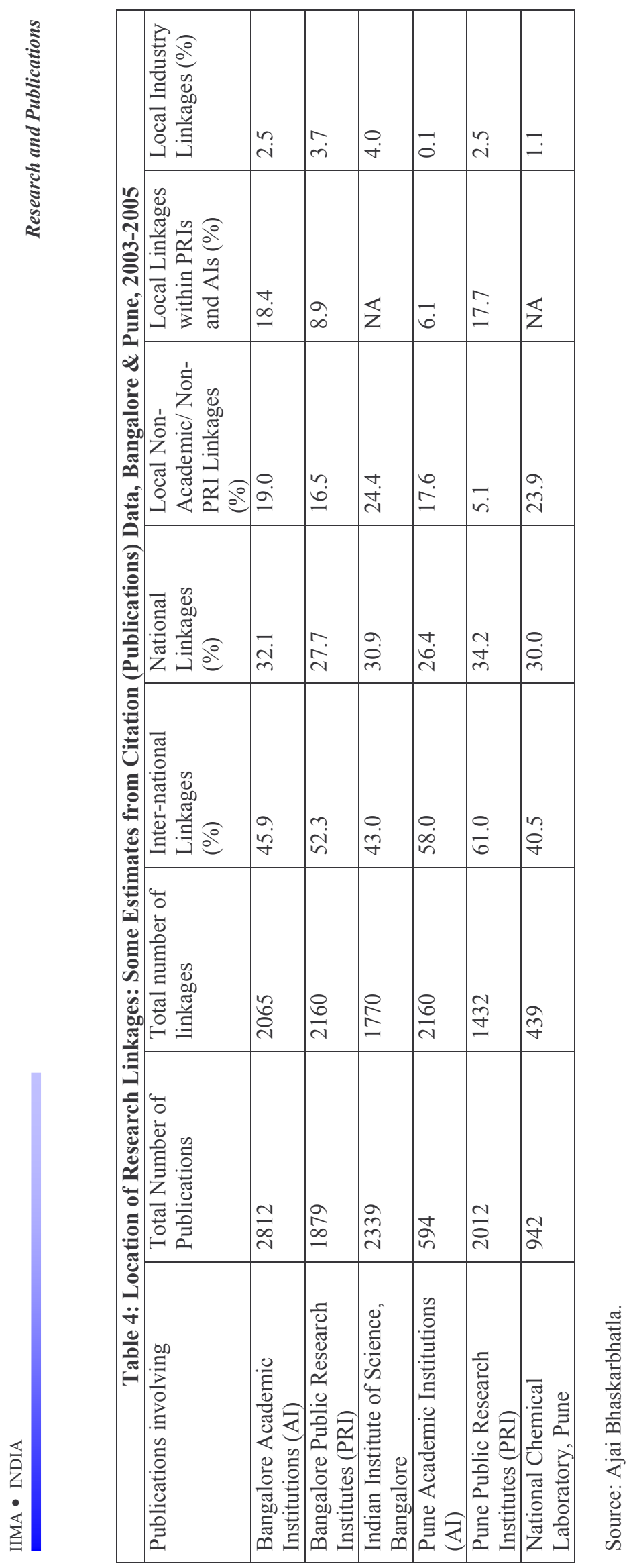




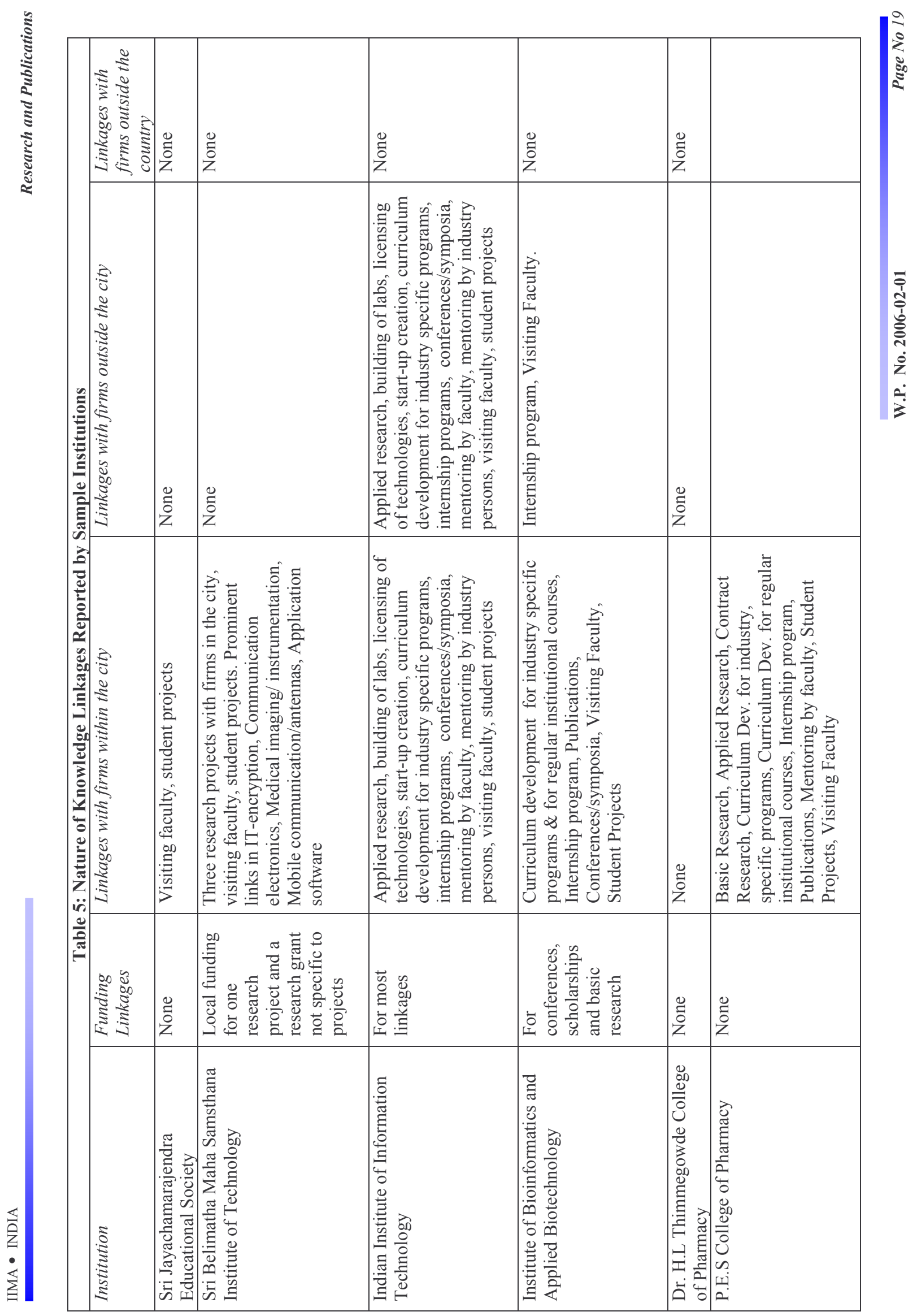




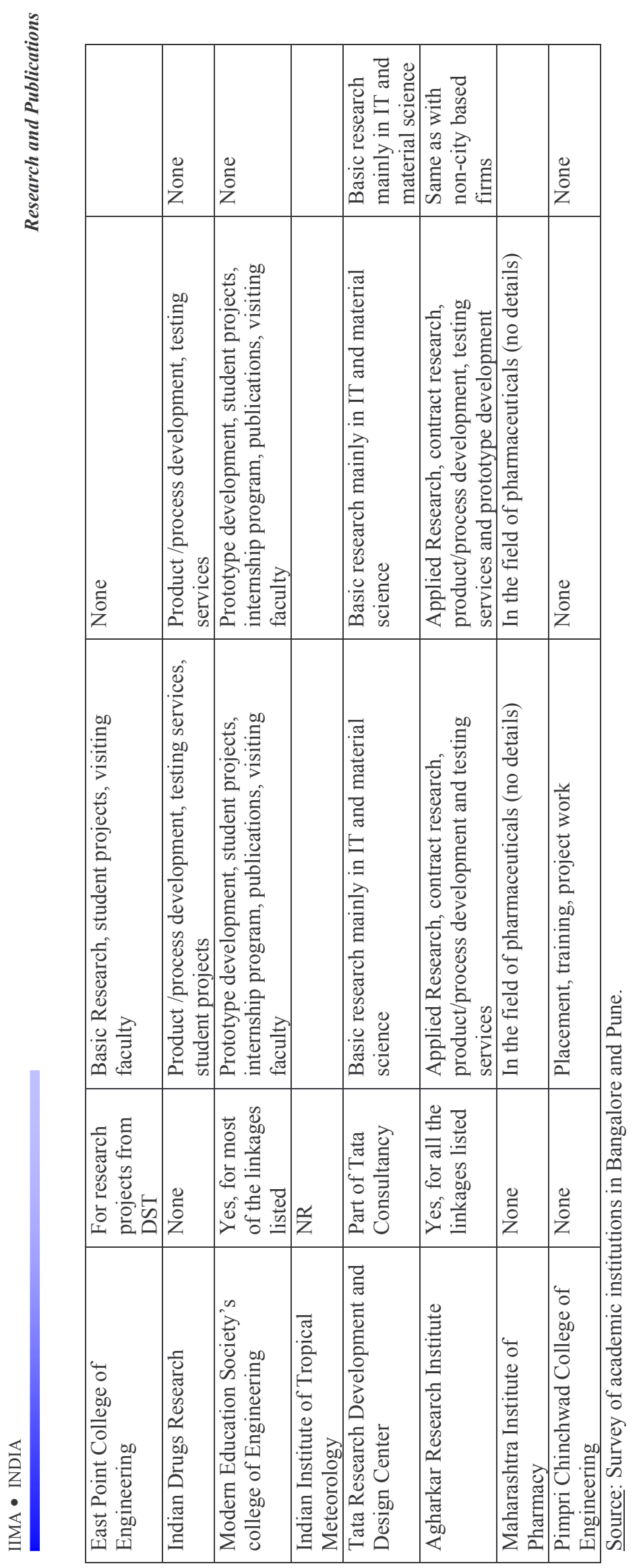


Table 6: A Summary of Linkages of Institute of Science, Bangalore

A. Spin-off Activity in the City

1. Strand Genomics. Spin off by 4 IISc scientists in the area of biotechnology. Within the campus.

2. Encore. Spin off by IISc scientists in the area of open source software and hardware. Within he city.

3. Pico Peta. Spin off based in Bangalore. Low cost computers -Simputer. Within city (2 local distributors).

4. MetaString Pvt. Limited. Spin off based in within the city

5. Esqube. Spin off based in the city in the area of DSP/Communications (Wi-Fi).

6. 3-D Solid Compression Pvt. Ltd. Spin off based in Bangalore. Collaboration between IISc, Stanford and

CMU. Alliance with local software company. Patented a data format.

7. Metahelix. Spin off from IISc. Contract research in genomics and bioinformatics. Within the city.

B. Alliances with Entities (Firms, institutions) within Bangalore

1. Cranes Software. IT company. Design and Testing/Micro \& Nanotechnology in acoustics + research center. On campus. Outside city alliances with a Chandigarh fab) and participation of US faculty. Lab seed funded by UGC. Both will equally share IPR that are directly funded by Cranes and IISc.

2. Ncore Pvt. Limited. Bangalore based. Design automation. Work within the campus. Funding by DoE (GOI) and Ncore

3. Texas Instruments. Bangalore subsidiary. Low power VSLI design + object oriented database + monthly student stipend. Work within campus.

4. Digital Equipment. Bangalore based firm. IISc consultancy in setting up lab + training on high performance computing. Within campus

5. Wipro. Bangalore based firm. Training in switching techniques.

6. Index computing. Bangalore based firm. Tech advice and help in neural networks. Within city.

7. BHEL. Bangalore based firm. Consultancy on multibus micro-processor system. Within city

8. Tata ELXSI. Bangalore. Training in artificial intelligence. Within city.

9. LG group. Bangalore. LG merit and best project award.

10. Jindal Vijaynagar. Bangalore based steel firm. COREX technology, and metallurgy related project.

11. Motorola India. Bangalore subsidiary. Develop software, training and consult on DSP

compilers/donation of DSP hardware and software.

12. BPL. Bangalore based subsidiary. Speech processing/ECE.

13. Govt. of Karnataka. Non conventional energy. Within campus and outside the city. Participation of Govt. of India.

14. Xserve. Bangalore based. Component supplier. Within city.

15. Microsoft. Bangalore (details not available).

16. All India Council for Technical Education. Bangalore. Telematics. Within campus (Joint research).

Some IITs are also involved and some work gets outside the city.

C. Alliances with Entities outside Bangalore but within the Country

1. Cadila Pharmaceuticals. Pharmaceutical firm based in Ahmedabad. Drug discovery + sponsored research +research center. Within campus. Funded by Cadila. IISc transferred two proteins found to Cadila.

2. Monsanto. Plant genomics. Sponsored research. Within campus.

3. Phillips. CPU/multi DSP systems/architecture for multimedia. Within campus.

4. Nicholas Piramal India Ltd (NPIL). Based in Mumbai. Identify potential new targets for developing

drugs to treat fungal infections. Within campus. Nicholas Piramal will have exclusive rights to

commercialize products coming out of this collaboration.

5. General Motors. Automobiles. Sponsored research/light weight engine/structural

materials/manufacturing processes. Within campus. GM assembling unit in Halol involved apart from some U.S Universities.

6. Lupin. Mumbai based. Develop drugs for TB. Within campus. Shanta Biotechnics, Hyderabad also involved. DST funded + Lupin pays the research fee.

7. DST. Central agency. Parallel distributed file system. Within campus.

8. Govt. of India. Central agency. Project on bio-mass energy for rural India. Within campus.

9. HLL. Bombay based. Project on fluid dynamics. Within campus.

10. HFCL, Delhi based. Work on digital signal processing. Within campus. Sponsored Project + research center). 


\begin{tabular}{|l|}
\hline 11. ALTECH. Fiction. Within campus (Project details not available) \\
\hline 12. FMC Rallis. Within campus (Sponsored research + research center. \\
\hline C. Alliances with Entities outside Bangalore but within the Country Contd... \\
\hline 13. Cookson Electronics. Manufacturing base in Chennai, supplier of materials and technology to \\
electronics assembly and semiconductor. Advanced electronics/materials/ceramics. Within campus \\
(Sponsor research+ research center+ sponsor graduate students). Cookson invested \$3-5 million + hired 45 \\
engineers. \\
\hline 14. Unichem. Biosciences-based in Mumbai. Within campus (Research center). \\
\hline 15. Satyam Computers. Chennai. Focus on IP creation in communications. Within campus (Research \\
center). \\
\hline 16. IBM. Within campus (Monthly student stipend for 12 months) \\
\hline 17. Analog Devices. Donation of DSP hardware and software. \\
\hline 18. Bharat Biotech. Vaccine development. Within campus (Outsourced work to IISc). \\
\hline 19. Shanta Biotechnics. Hyderabad based. Protien development. Within campus (Sponsored research). IISc \\
transferred a protein found to Shanta. \\
\hline 20. TVS Motors. Head office-Chennai. Within campus (Sponsored research). 6 patents developed by IISc. \\
1\% royalty to TVS+ a fixed amount for 2 years, investment over Rs 3 crore. \\
\hline 21. DuPont. Polymers. DuPont Chair. Within city \\
\hline 22. IISc also has alliances with the following: Tata Center for tropical disease, Department of Electronics, \\
Department of Telecommunication, Defence Research and Development Organization, Indian Telephone \\
Industry and Indian Space Research Organization. Details not available. \\
\hline D. Alliances with Entities Outside Country \\
\hline 1. Nortel. U.S based. Project on cellular telephony. On campus. \\
\hline 2. Northern Telecom NORTEL. California based. Develop switch algorithms/ECE. Within campus. \\
\hline 3. Nokia. Finland. Within campus. Several research projects \& advanced training programs for students. \\
\hline
\end{tabular}

Source: Press clippings and business articles. 


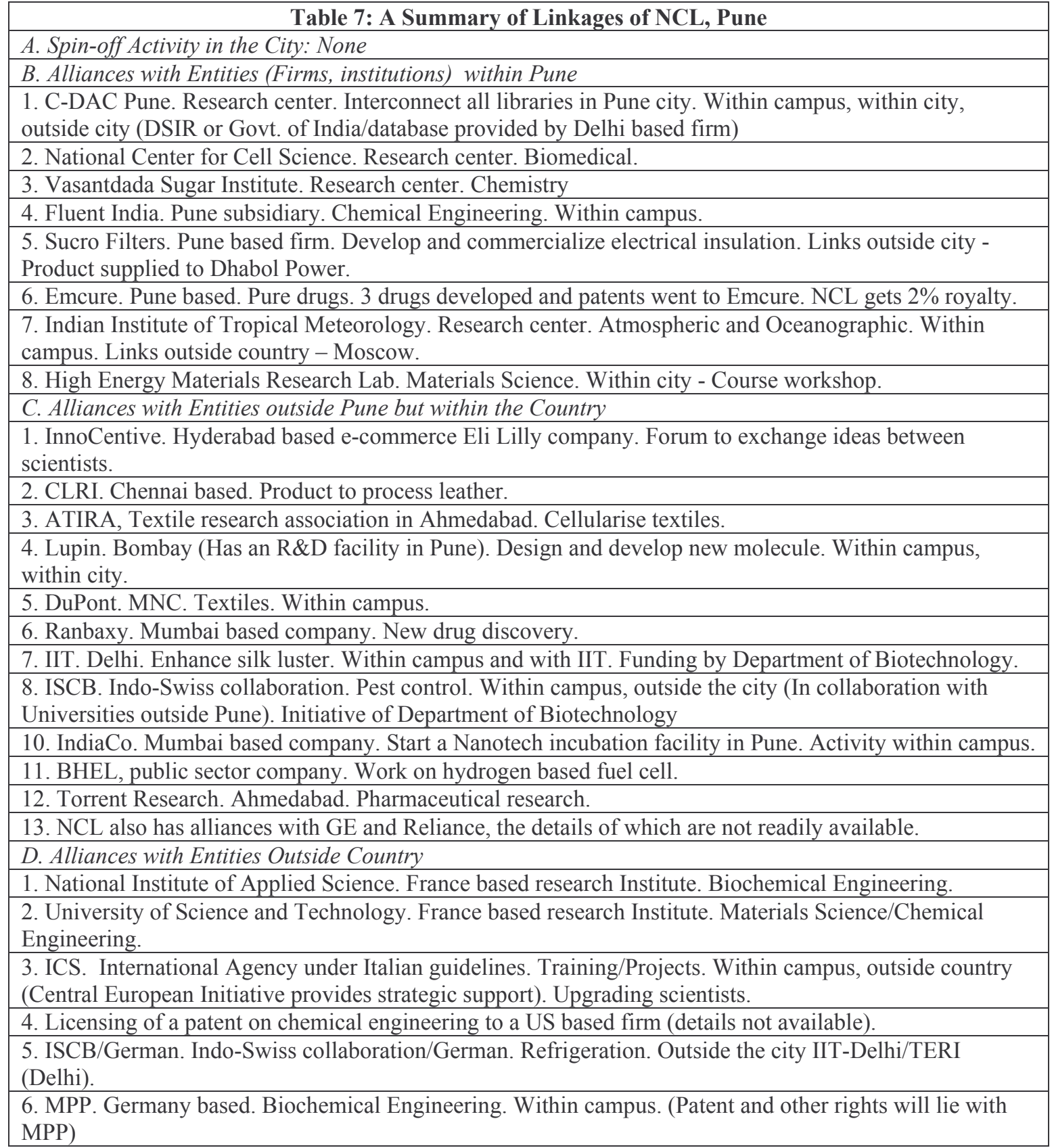

Source: Press clippings and business articles. 


\section{End Notes}

${ }^{1}$ See, for example, Adams (2001), Arundel and Geuna, (2001), Athreye (2004), Best (2000), Lawson (1999) and Saxenian (1994).

${ }^{2}$ The survey covered IT and electronics firms and in that sense, the responses are specific to these two sectors.

${ }^{3}$ These estimates are not reported here to save space.

${ }^{4}$ See Basant and Rani (2004) for a detailed discussion of the labour market deepening processes.

${ }^{5}$ The discussion in the following paragraphs is essentially based on Basant and Rani (2004).

${ }^{6}$ This is mainly because export market projects are often less complex than domestic projects but are more lucrative (For details see Basant and Chandra, 2003).

${ }^{7}$ The onsite share declined from $90 \%$ in $1990-91$ to about $39 \%$ in $2002-03$.

${ }^{8}$ Basant (2004a) documents, to the extent the available data permits, that such a transition is indeed taking place. Some evidence of this transition is also available in Venkatraman, Mukundan and Shankar (2003).

${ }^{9}$ These technological changes can potentially "disintegrate" the semi-conductor industry providing niche opportunities for small firms (Linden and Somaya, 2003) and for collaborative arrangements.

${ }^{10}$ See, Basant (2004b) for details on these opportunities.

${ }^{11}$ Strand Genomics, a spin out firm from Indian Institute of Science, Bangalore is a prime example of this trend. Other firms active in this domain include Agilent Technologies (Life Sciences and Chemical Analysis), Wipro Health Science, and Kshema (Mphasis Technologies) Technologies.

${ }^{12}$ There is considerable debate about what is appropriate as an IPR regime as conditions differ considerably across regions. In the context of countries like India where significant technological capabilities exist but access to resources (even of the large corporate firms) does not match with the resources available to developed country firms, an IPR system that creates incentives to invent and facilitates participation of local firms in global research and production networks seems sensible. The move to a product patent regime that has taken place, data security and better implementation of IP laws is likely to enhance the probability of Indian firms/institutions participating in global research networks. Their participation in global production networks involving IP based products and processes are also expected to rise. The jury is still out on the utility of protecting incremental inventions (petty patents) and new use patents in chemicals and pharmaceuticals industries. Since Indian firms can manage such inventions more easily, they can benefit from such protection, especially through licensing. But such a policy also creates possibilities of ever-greening that will benefit large developed country firms.

${ }^{13}$ According to some estimates, Pune's educational institutions produce more than 3000 IT professionals every year (Dataquest, 2001).

${ }^{14}$ For example, the Pune bio-tech sector includes large-scale bio-processing (Alfa-Laval, Praj Industries), vaccines (Serum Institute), GM crops (Mahyco, Syngenta), bio-therapeutics (Wockhardt) and enzymes (Advanced Bio-chemicals).

${ }^{15}$ Bangalore is also emerging as a diverse bio-tech cluster. It covers enzymes (Biocon), bio-therapeutics (Biocon, Gangagen), bio-informatics [Strand Genomics, Bigtech, Kshema (now part of Mphasis Technologies), CDC Linux, Molecular Connections], plant genetics and genomics (Avesthagen, Monsanto, Metahelix, Advanta), contract R\&D (Syngene, Aurigene, Genotypic Technology, Avesthagen, Bangalore Genei), and bio-processing and bio-instrumentation (Sartorius, WIPRO-GE, Photonics and Bio-molecules, Bangalore Genie, Millipore).

${ }^{16}$ To save space detailed data is not reported here.

${ }^{17}$ IIIT, Bangalore received 13 patents and 13 more are pending. Tata Center in Pune developed 50 new products, got about 60 patents, 20 more are pending, licensed 4 technologies is negotiating for 2 more. The Agharkar Institute developed 3 new processes, got 11 patents and 9 more are pending.

${ }^{18}$ Most of the other material in this paragraph is from Indian Institute of Science Website www.iisc.ernet.in

${ }^{19} \mathrm{IISc}$ has around 9718 research publications from 1985 to 1996 (source:

http://www.ncsi.iisc.ernet.in/iisc publications.php). Besides, there are around $5000 \mathrm{PhD}$ theses done at

IISc since its inception (www.iisc.ernet.in).

${ }^{20}$ Most of the other material in this paragraph is from NCL website www.ncl-india.org 


\section{REFERENCES}

Adams, J.D. (2001), "Comparative Localization of Academic and Industrial Spillovers", NBER Working paper Series 8292, NBER Cambridge.

Arundel, A. and Aldo Geuna (2001), "Does proximity Matter for Knowledge Transfer from Public Institutes and Universities to Firms", Electronic Working Paper Series 73, SPRU, University of Sussex.

Athreye, S. (2004), "Agglomeration and Growth Study of the Cambridge High-tech Cluster". In T.F. Bresnahan and A. Gamberdella (Eds.), Building Hi-tech Clusters: Silicon Valley and Beyond. Cambridge MA: Cambridge University Press.

Basant, R. (2004a), "U.S.-India Technology Cooperation and Capability Building: The Role of Inter-firm Alliances in Knowledge-Based Industries", East-West Center Occasional Papers, Economics Series, No. 2, January.

Basant, R. (2004b), "Intellectual Property and Innovation: Changing Perspectives in the Indian IT Industry", Vikalpa, 29 (4), 69-82.

Basant and Chandra (2003), "Inter-organization Linkages in the IT Industry in India: A Case Study of Telecom Technologies". In A D'Costa and E. Sridharan (eds.), The Context of Innovation in India: The Case of the IT Industry. London: Palgrave.

Basant, R and Uma Rani (2004), "Labor Market Deepening in India's IT: An Exploratory Analysis", Economic and Political Weekly, XXXIX (50), 5317-5326.

Branscomb, L M et al (eds.) (1999), Industrializing Knowledge: University-Industry Linkages in Japan and the United States, MIT Press.

Best, M.H. (2000) "Silicon Valley and the Resurgence of Route 128: Systems Integration and Regional Innovation" in John H. Dunning, (ed.) Regions, Globalization and the Knowledge-based Economy, Oxford University Press, 2000;

Business World (2003), "Potent Research", May 19, 44-48.

Dataquest (2001), "Nasscom, Nasdaq Coming to Pune", April 28.

De, R (2004), "Pune Special”, Dataquest, September 23.

Geiger, R L (2001), "Industrializing Knowledge: University-Industry Linkages in Japan and he United States", Journal of Economic Literature, 39 (1).

Graff, G et al, (2002), "University Research and Offices of Technology Transfer", California Management Review, 45 (1), 88-115.

Linden, G and Somaya, D (2003). "System-on-a-chip Integration in the Semiconductor Industry: Industry Structure and Firm Strategies," Industrial and Corporate Change, 12 (3), 545-576.

Mani, S (2002), Government, Innovation and Technology Policy: An International Comparative Analysis, Edward Elgar.

Morris, S and R Basant (2005), "Role of Small Scale Industries in the Age of Liberalization". The Policy Group on Trade and Industry, Asian Development Bank, New Delhi and Manila, April.

Motohashi, K (2004), "University Industry Collaboration and the Importance of R\&D Focused Small and Medium Enterprises-Their Implications on Japan's Innovation System”, Research and Review, Research Institute of Economy, Trade and Industry Review (http://reiti.go.jp/en/papers/research ).

Mowery, D C and B N Sampat (undated), "Universities in national innovation systems" www.vannevar.gatech.edu/papers/Fagerberg_June29.pdf

Lawson, C (1999), "Towards a Competence Theory of a Region", Cambridge Journal of Economics, 23(2), March, pp. 151-166.

Saxenian, A.L. (1994), Regional Advantage: Culture and Competition in Silicon Valley and Route 128. Cambridge, MA: Harvard University Press.

Venkatraman, A, D. Mukundan and G.V. Ravi Shankar (2003)," Enabling the Transition of the Indian Software Industry from Services to Products", Independent Project Report, Indian Institute of Management, Ahmedabad, India. 